\title{
Investigating the effectiveness of drain infiltration to minimize peat oxidation in agricultural fields in Flevoland, the Netherlands
}

\author{
Frouke Hoogland, Arjen S. Roelandse, Beatriz de La Loma González, Maarten J. Waterloo, \\ Perry W. Mooij, Sabine A. Verhagen, and Jouke Velstra
}

Acacia Water B.V., van Hogendorpplein 4, Gouda, 2805BM, the Netherlands

Correspondence: Frouke Hoogland (frouke.hoogland@acaciawater.com)

Published: 22 April 2020

\begin{abstract}
In the Province of Flevoland, the Netherlands, land subsidence poses a problem to agriculture and water management. The peat layers in the soil are susceptible to compression and oxidation causing further subsidence. Applying subirrigation through the tile drain system to maintain saturation of the peat may be a measure to slow down subsidence. A study was therefore carried out at two sites, Nagele and Zeewolde, to assess the impact of subirrigation in the peat on the seasonal variation in soil moisture content, and corresponding redox conditions. Bacterial community analysis was carried out to verify the hydrochemical observations. Subirrigation proved to be an efficient measure to maintain a high water level in the peat soil as long as the permeability in the upper part of the peat was sufficient to allow transmission of water into the inter-drain area and when the peat layer extended enough below the minimum regional water level to prevent drainage to the sand layer underneath. The peat showed dual porosity and water levels could well be maintained by subirrigation at the Nagele site. At the Zeewolde site, the variability in the thin peat layer allowed drainage to occur in the sand layer, preventing subirrigation to maintain high water levels. However, at both sites the peat layer remained close to saturation throughout the summer, which may be caused by the fine-grained mineral layer isolating the peat from water extraction via evapotranspiration. Nitrate concentrations of up to $100 \mathrm{mg} \mathrm{L}^{-1}$ were observed were high $\left(>50 \mathrm{mg} \mathrm{L}^{-1}\right)$ in the oxic mineral top layer but were low in the peat $\left(0.3 \mathrm{mg} \mathrm{L}^{-1}\right)$ at both Nagele and Zeewolde sites. Sulphate concentrations also showed a decrease with depth in the peat at Nagele, indicating a transition from sub-oxic above $1.5 \mathrm{~m}$ depth to anoxic conditions at $3.5 \mathrm{~m}$ depth. The hydrochemical observations in the soil moisture in the peat at Nagele confirmed that conditions were sub-oxic in the upper part of the peat $(0.7 \mathrm{~m}$ below soil surface) to anoxic at greater depth $(3.5 \mathrm{~m})$. Soil microbe analyses showed few nitrification bacteria in the peat, whereas communities specialised in denitrification and ammonification were present, as well as sulphate reducing bacteria and methanogenic species. This confirmed the sub-oxic to anoxic conditions in the peat deduced from the hydrochemical observations. At Zeewolde, conditions remained sub-oxic throughout the profile.
\end{abstract}

\section{Introduction}

The Flevoland polders were reclaimed in the mid-20th century from the former Zuiderzee, which was closed off from the North Sea to form the fresh water IJsselmeer lake. The land surface is currently about 3-4 m below sea level, and subsidence continues (Fokker et al., 2015) posing a significant threat to agricultural practices (Vogelenzang et al.,
2019), complicating water management and threatening water quality by increased upward seepage of saline water. Main causes of subsidence were the loss of pore pressure following reclamation and subsequent gradual lowering of phreatic water levels by the Water Board to create and maintain favourable conditions for agriculture. This resulted in compression and compaction of the clayey top soil layer and the peat layer underneath. An important factor for contin- 
ued subsidence is the oxidation and permanent shrinkage of shallow humic clay and peat layers (Fokker et al., 2015). Peat oxidation can account to up to $68 \%$ of loss in volume (Leifeld et al., 2011) and is fastest at high oxygen availability and high soil temperatures. Peat oxidation conditions are therefore most favourable during summer when phreatic levels decrease in response to evapotranspiration and nearsurface peat layers partially dry out. Land use in Flevoland is mainly agricultural. About $71 \%$ of agricultural land is used for intensive arable farming of potatos, wheat, sugar beet and onions, which requires phreatic levels of at least $0.8 \mathrm{~m}$ below the surface. Peat meadows for production of grass or corn fodder cover about $21 \%$ (Vogelenzang et al., 2019). For arable farming, tile drain systems and regulation of the regional water level by the Water Boards keep groundwater levels low, even during high rainfall events. Inter-drain distances are typically between 12 and $30 \mathrm{~m}$. In peat meadows, drainage is accomplished by a system of shallow ditches dug at typical inter-distances of more than $30 \mathrm{~m}$ (Couwenberg, 2018).

In summer, the lowering of the regional water level by the Water Board and high crop evapotranspiration cause a decline in phreatic water level, thereby allowing oxygen to enter the soil pores causing potential for enhanced decomposition and shrinkage of peat. A possible method to reduce the risk of subsidence in agricultural areas with shallow peat layers is to adapt the tile drain system for subirrigation, such as to allow active infiltration into the peat and maintain a higher water level in the soil. This requires transmission of water from the drains into the inter-drain space. The degree of success of subirrigation therefore depends on if the infiltration capacity is high enough to balance the extraction of soil moisture in the inter-drain space for evapotranspiration. Peat often exhibits dual porosity, with higher permeability in interconnected macropores and low permeability in the matrix (Rezanezhad et al., 2016). Permeability generally decreases with depth and low permeabilities require small inter-drain distances to maintain moist conditions in the area between the drains. Within the "Spaarwater Flevoland" project the effects of active tile drain infiltration on phreatic water levels and soil moisture content between drains and on peat oxidation processes were investigated at two agricultural plots in the dry summers of 2018 and 2019. The objectives were to assess the rate of infiltration through the tile drain system to maintain a uniform phreatic level, and if subirrigation could prevent the soil water from becoming oxic. The latter was studied using hydrochemical and microbiological analyses.

\section{Site description}

Soils in Flevoland show considerable heterogeneity due to temporal and spatial variations in the depositional environments in the Holocene. Sand and peat deposits occurred in tidal marshes, which were overlain by fine-grained deposits

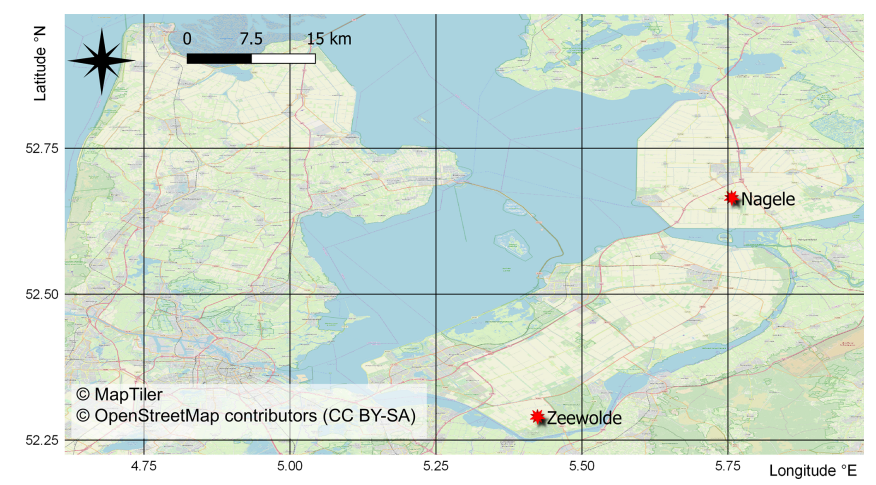

Figure 1. Locations of the Zeewolde and Nagele sites in the Flevoland Province, east of Amsterdam, in the Netherlands. (C) MapTiler and (C) OpenStreetMap contributors 2020. Distributed under a Creative Commons BY-SA License.

of varying thickness. The soil in Flevoland is characterised by a sequence of a fine-grained mineral top layer on a peat layer formed on sand. Two pilot sites were selected with different soil layering and thickness of the peat layers. The locations of the Zeewolde and Nagele pilots are presented in Fig. 1.

\subsection{Nagele site}

The soil at the Nagele site $\left(52^{\circ} 39^{\prime} 55^{\prime \prime} \mathrm{N}, 5^{\circ} 45^{\prime} 22^{\prime \prime} \mathrm{E}\right.$, $-4 \mathrm{~m}$ a.s.1.) is characterised by a $0.3-0.5 \mathrm{~m}$ deep top layer of silty clay underlain by about $2.5 \mathrm{~m}$ of peat formed on sand (Velstra et al., 2015). The tile drains were at a depth of $0.8-$ $0.9 \mathrm{~m}$ below the surface with an inter-drain spacing of $12 \mathrm{~m}$. New tile drains were installed between the original drains in the peat layer, applying a sand filling on the drain up to the surface. This brought the inter-drain distance to $6 \mathrm{~m}$ in both experimental and reference fields. In dry summers, such as those of 2018 and 2019, the farmer applies subirrigation by setting up water level in the ditch above the drain outlets to reach a maximum water level of $0.7 \mathrm{~m}$ below the soil surface. The crop rotated between grass in 2017, to potatoes in 2018, and onion in 2019. Crop roots were not observed in the peat layer. The subsidence in this area has been estimated at 2-3 $\mathrm{mm} \mathrm{yr}^{-1}$ (Source: Bodemdalingskaart.nl, Nederlands Centrum voor Geodesie en Geo-informatica (NCG)).

\subsection{Zeewolde site}

The soil at the Zeewolde site $\left(52^{\circ} 17^{\prime} 22^{\prime \prime} \mathrm{N}, 5^{\circ} 25^{\prime} 25^{\prime \prime} \mathrm{E}\right.$, $-4 \mathrm{~m}$ a.s.l.) showed more spatial variation in the layering. The top layer of silt/clay, with a thickness of $0.5-1.1 \mathrm{~m}$, was deposited on a $0.05 \mathrm{~m}$ thin sand layer. A peat layer of varying thickness $(0.2-1.1 \mathrm{~m})$ and with a thin clay layer at its base was subsequently observed. The base layer consisted of sand at $1.2-1.6 \mathrm{~m}$ below the surface (Velstra et al., 2015). The tile drains were at a depth of $0.8-0.9 \mathrm{~m}$ below the surface with 
an inter-drain spacing of $16 \mathrm{~m}$. New tile drains were again installed between the original drains in the clay/peat layers, applying sand filling up to the surface, which brought the interdrain distance to $8 \mathrm{~m}$. Crop rotation was typical for Flevoland including sugar beet, onions and potatos. Crop roots were not observed in the peat layer. The subsidence in this area was somewhat lower at about $1 \mathrm{~mm} \mathrm{yr}^{-1}$ (NCG).

\section{Methods}

For subirrigation, the tile drains were connected to a collector drain and buffer tank, in which provisions were made to allow fixing water levels at $0.1 \mathrm{~m}$ level increments, independent of the ditch water level. A solar pump was used to supply water to the buffer tank from the ditch to maintain a set water level. Percolating rain water was removed by overflow in the drain well to the ditch. This system allows subirrigation in the experimental plot to be better regulated and at higher water levels than possible in the regular ditch approach. Flows into and out of the drains were continuously monitored with flow meters (Octave; Arad, Israel). Phreatic water level measurements were made in transects perpendicular to tile drain directions. Piezometers were installed next to the drains and at $0.5-1.0 \mathrm{~m}$ intervals in the interdrain space for continuous phreatic water level measurements (CTD-10; Decagon, USA). Soil moisture content profiles were measured (GS3; Decagon, USA) down to a depth of $0.75 \mathrm{~m}$. Soil moisture and groundwater samples were extracted at two-week intervals using rhizons (Rhizosphere Research Products, the Netherlands) installed at 0.25, 0.50. and $0.75 \mathrm{~m}$ depths. Deeper groundwater was sampled at 1.5 and $3.5 \mathrm{~m}$ depth (sand layer) from piezometers, which were duly flushed before sampling. Samples were filtered (0.2 $\mu \mathrm{m}$ PES) and analysed at the laboratory of Acacia Water for major cat- and anions using ion chromatography (Aquion; Dionex, USA). Fe and Mn ion concentrations were determined colorimetrically (DR900; Hach, USA).

Bulk soil samples (three locations at Nagele) for identification of bacterial communities in view of their potential to reduce nitrate and sulphate were taken at depths of 0.7 and $2.2 \mathrm{~m}$ in the peat layer. Sampling was carried out at the end of the winter season (6 March 2019) in prepared sample bottles and were analysed using next generation sequencing (ORVIdecode) at Orvion (the Netherlands). This procedure allows characterization of DNA and identification of bacteria populations.

\section{Results}

\subsection{Groundwater level and soil moisture content}

Ground water level measurements at Nagele showed discharge towards the drain from the inter-drain space in the winter period, with higher water levels in the piezometer between the drains than that at the drain (Fig. 2). In the summer of 2018, the pump was not capable to supply enough water to the drains and the water level between the drains decreased following the deeper regional trend. In the summer of 2019 , the farmer decided to increase the water level to the bottom of the clay layer at about $0.5 \mathrm{~m}$ below the surface and infiltration occurred such that the peat remained saturated despite the decrease in the regional ground water level. The situation in summer 2019 showed that the peat layer was permeable enough at drain depth $\left(\mathrm{Ks}=0.1-0.2 \mathrm{~m} \mathrm{~d}^{-1}\right)$ to allow flow of water into the inter-drain spacing. In addition, the thickness of the peat layer and permeability at depth were such that leakage to the deeper sand layer seemed minimal, allowing for a stable higher water level in the peat than in the sand layer below. The soil moisture content $\theta$ at a depth of $0.7 \mathrm{~m}$ remained close to saturation, varying between 0.71 and 0.75 , except for the period between 20 June and 25 August 2018 when not enough water could be supplied to the drains and $\theta$ gradually decreased to 0.61 . This suggests that the peat at this depth became unsaturated and in contact with oxygen.

In Zeewolde, where the peat layer was less deep and the drains were locally in the base sand layer, it was not possible to supply enough water to maintain a high level in the peat layer because of leakage to the regional groundwater system through the sand layer. The water levels in the peat layer therefore followed the regional trend (Fig. 3).

The decline in phreatic level during the dry period did not have a large effect on $\theta$ at a depth of $0.7 \mathrm{~m}$ in the peat (Fig. 4). The moisture content in peat at Zeewolde reference showed very little variation between winter and summer seasons, even though the summer of 2018 was extremely dry. Moisture content at the Nagele reference site showed seasonal variation in the first year, but less in the second year as the farmer decided to use tile drain subirrigation to keep the peat moist in summer.

In Zeewolde, the experimental site showed a fluctuating moisture content, peat being saturated in wet periods $\theta=$ 0.77 ), followed by a fast drop to $\theta=0.75$. This pattern suggests rapid draining of macropore space (about $2 \%$ ), with remaining moisture staying immobile in the peat matrix. The soil moisture content in the peat of the experimental plot in Nagele maintained its high moisture content until the water supply to the tile drains was interrupted by mid-June 2018 . This was followed by a decline in $\theta$ to 0.61 by August. In the summer of 2019, the water content remained high, except during short periods when the pump malfunctioned. The fast decrease in $\theta$ after pump failure also suggest draining of the macropore space, rather than of the matrix. The top finegrained mineral soil layer, with its relatively high plant available water, provided most of the moisture for evapotranspiration. Roots were not observed in the peat layer, presumably also because of the continuously high moisture content. The peat layer at Zeewolde seemed also to be isolated from the sand layer below due to the thin impermeable clay layer at its base preventing drainage. The small ranges in observed $\theta$ 


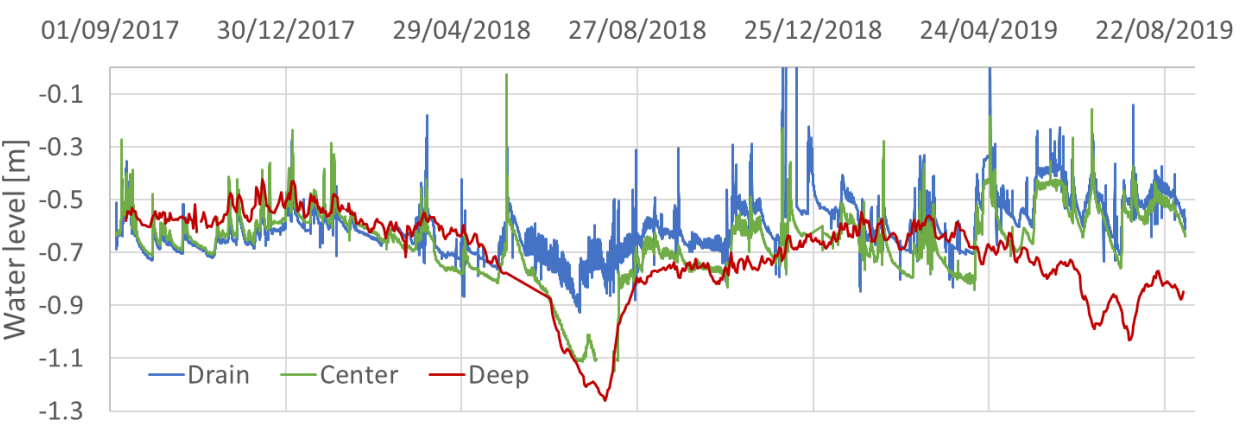

Figure 2. Groundwater levels in the experimental field at Nagele, where the drain well was used to maintain fixed water levels in summer. Drain is on the drain, centre is between the drains and deep is the groundwater level in the deep sand layer (regional). Note that the piezometers were dry at water levels below $1.1 \mathrm{~m}$.

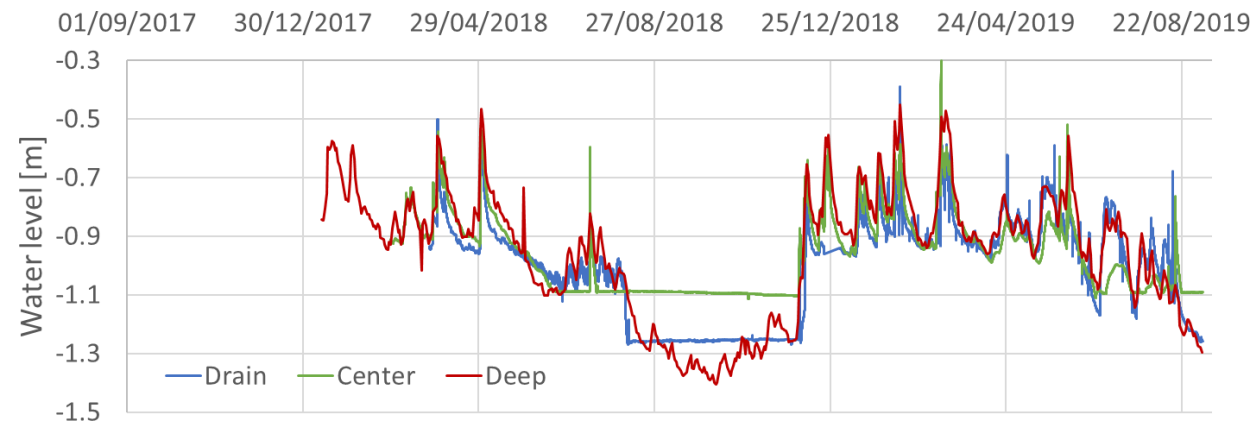

Figure 3. Groundwater levels in the experimental field at Zeewolde, where the drain well was used to maintain fixed water levels in summer. Drain is on the drain, centre is between the drains and deep is the groundwater level in the deep sand layer (regional). Note that the piezometers were dry at water levels below $1.1 \mathrm{~m}$.

indicate that the soil moisture tensions remained low at above $-50 \mathrm{hPa}(\mathrm{pF}=1.7)$.

\subsection{Hydrochemistry}

Electrical conductivity of soil moisture in the peat at $0.75 \mathrm{~cm}$ depth was relatively high at $2743 \pm 839 \mathrm{uS} \mathrm{cm}^{-1}$ in the reference plot and $2031 \pm 487 \mathrm{uS} \mathrm{cm}^{-1}$ in the subirrigated plot, which may reflect the saline environment from which the land was reclaimed. The corresponding $\mathrm{pH}$ values ranged from 5.53-7.65 in the reference plot to consistently higher values of 5.90-8.70 in the subirrigation plot. Both plots showed seasonal variation in $\mathrm{pH}$, with the highest values observed in the summer season. Atmospheric oxygen has to travel through the fine-grained top layer before reaching the peat. This is mainly by diffusion, although cracks formed during drying in summer and could have formed preferential gas flow paths towards the peat layer. If the macropores in the peat drain oxygen may enter but may not reach the peat matrix regions where moisture is immobile. When oxygen is present, this is preferably used in the decomposition process by bacteria. Stuyfzand (1993) and Mendizabal (2011) have defined different redox zones in soils related to the presence of certain ions (e.g. $\mathrm{NO}_{3}, \mathrm{SO}_{4}$ ) or dissolved gases (e.g. $\mathrm{O}_{2}, \mathrm{H}_{2} \mathrm{~S}$ ) in groundwater. Analyses of water ex- tracted from different depths in the peat therefore provides information on the redox status. At a depth of $0.5 \mathrm{~m}$ in the top layer of fine-grained soil nitrate concentrations were observed up to concentrations of $100 \mathrm{mg} \mathrm{L}^{-1}$, with an average of $43 \pm 45 \mathrm{mg} \mathrm{L}^{-1}$. As the surface layer is unsaturated and exposed to the atmospher the conditions ca be considered oxic. In the peat layer below, $\mathrm{NO}_{3}$ concentrations were low, averaging to $0.3 \pm 0.5$ and $0.07 \pm 0.29 \mathrm{mg} \mathrm{L}^{-1}$ at 0.75 and $1.5 \mathrm{~m}$ depths, respectively. $\mathrm{NO}_{3}$ concentrations did not increase in peat in response to the decreasing moisture content in June-August 2018, suggesting sampling of water from immobile regions in the peat with the rhizons. $\mathrm{SO}_{4}$ concentrations, however, did increase in the samples during the dry period, indicating that $\mathrm{SO}_{4}$ was produced at $0.75 \mathrm{~m}$ depth. With $\mathrm{SO}_{4}$ concentrations of well over $500 \mathrm{mg} \mathrm{L}^{-1}$ (and generally low $\mathrm{Fe}$ and $\mathrm{Mn}$ ion concentrations) the redox conditions at 0.75 and $1.5 \mathrm{~m}$ depth could be classified as sub-oxic. Nitrate was also absent in samples taken from the piezometer at $3.5 \mathrm{~m}$ depth, and $\mathrm{SO}_{4}$ concentrations were strongly reduced to an average of $12 \pm 12 \mathrm{mg} \mathrm{L}^{-1}$. Furthermore, the release of $\mathrm{H}_{2} \mathrm{~S}$ gas was observed during sampling at depths below $2 \mathrm{~m}$. The water chemistry in the peat layer in Nagele therefore indicated that the redox environment changed from sub-oxic at $0.75-1.5 \mathrm{~m}$ to anoxic/deep anoxic at $3.5 \mathrm{~m}$ depth. 


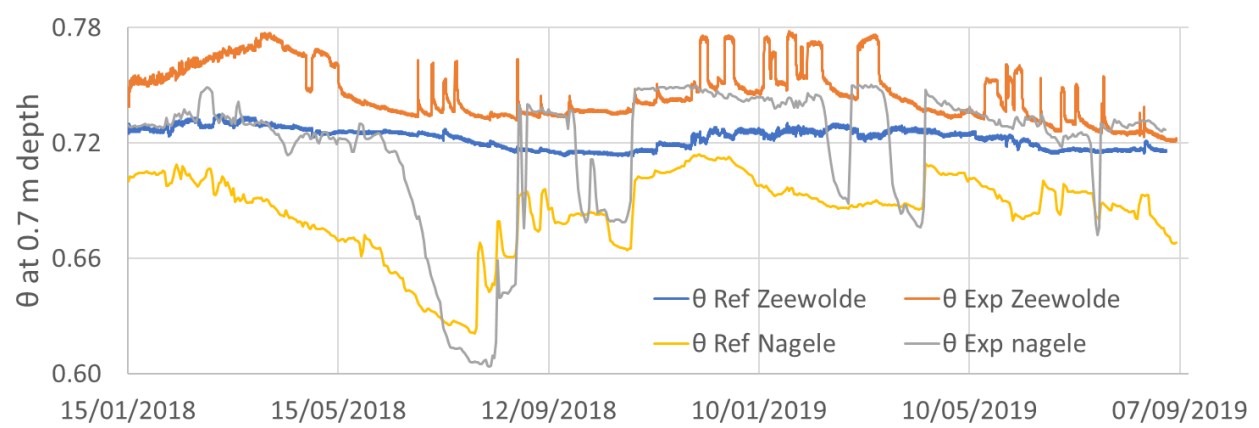

Figure 4. Variation in soil moisture content $(\theta)$ at $0.7 \mathrm{~m}$ depth in peat for reference (Ref) and experimental (Exp) plots in Zeewolde and Nagele.

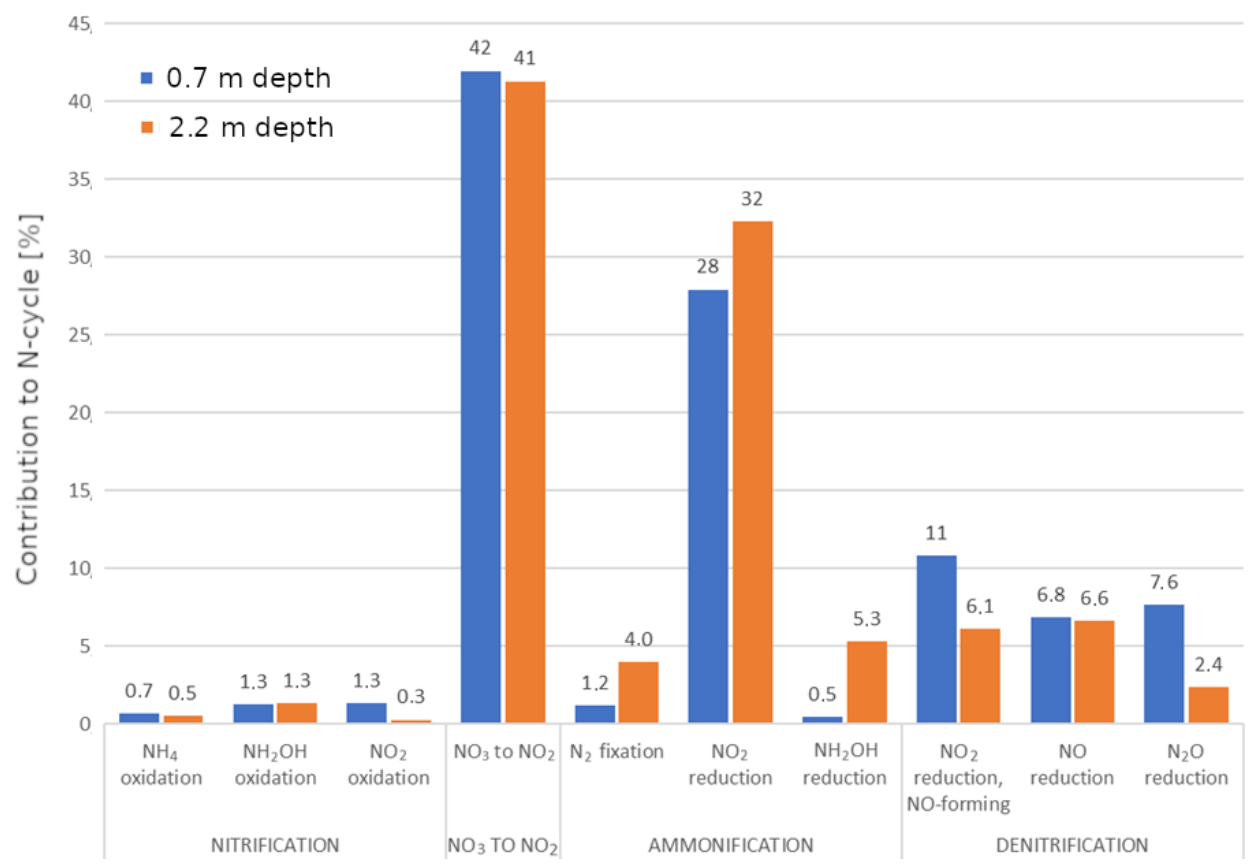

Figure 5. Contribution of bacterial communities to nitrogen transformation processes in the peat layer at depths of $0.7 \mathrm{~m}$ (sub-oxic) and $2.2 \mathrm{~m}$ (anoxic) in Nagele, March 2019.

The peat decomposition process is slowed down with depth as the electron donors change with depth from initially $\mathrm{NO}_{3}$ to finally $\mathrm{SO}_{4}$. Similarly, low $\mathrm{NO}_{3}$ concentrations were observed in the peat in Zeewolde, but $\mathrm{SO}_{4}$ concentrations were much higher throughout the peat/sand profile and the conditions therefore remained sub-oxic.

\subsection{Analyses of bacterial communities in peat}

Salinity and redox status influence the microbial biomass and metabolic activity related to the mineralization of carbon in peat, with $\mathrm{pH}$ being an important factor controlling the microbial diversity (DeAngelis et al., 2010; Preston et al., 2012; Tecon and Or, 2017). In the upper part of the peat oxygen seems to be absent, but nitrate percolating down from the unsaturated top layer can provide the oxygen used for de- composition by nitrate reducing bacteria. Lower in the profile, nitrate has been consumed and the bacterial population could change to include species that specialise in the reduction of, for instance, sulphate. At Nagele, the analysis indicated that bacteria were present in much larger numbers in the shallow suboxic peat sample than in the deeper anoxic sample. In both samples proteobacteria were dominant accounting for $70 \%$ of the population DNA, with alpha- and betaproteobacteria accounting for about $50 \%$. Terrabacteria groups (mainly actinobacteria) accounted for another $10 \%$. Differences were observed in the presence of Gemmatimonadetes at $2 \%$ in the sub-oxic sample and at $0.8 \%$ in the anoxic region. Chloroflexi and Firmicutes bacteria increased from $0.3 \%$ and $0.4 \%$ in the sub-oxic region to $2 \%$ and $1 \%$ in the anoxic region, respectively. Planctomycetes, known to perform nitrite reduction and ammonium oxidation anaerobi- 
cally (Dong et al., 2009; Fuerst, 2017), was present at about $1.0 \%$ in both samples. The analyses showed that nitrificating bacterial communities typical for oxic conditions were virtually absent (Fig. 5), supporting the observation that dissolved oxygen concentration remained low in the peat.

The fractions of bacteria specialised in denitrification (mainly $\mathrm{NO}_{3} \rightarrow \mathrm{N}_{2}$ ) were only slightly lower in the anoxic region, but the fractions of ammonification bacteria species were higher than those in the suboxic region. The latter suggests increased limitations in the availability of nitrate with depth. Sulphate reducing bacteria (Desulfarcales, Desulfobacterales, Desulfovibrionales and Desulfuromonadales from the deltaproteobacteria class) were also observed in both samples, making up $0.7 \%$ of the total population in the sub-oxic region and $1.9 \%$ in the anoxic region. The percentages of methano-microbia were low but increased with depth from $0.03 \%$ to $0.11 \%$ of the DNA present.

\section{Conclusions}

The study shows that several conditions need to be met for keeping a peat layer saturated through subirrigation by infiltration of water through the tile drain system. The first condition is that the inter-drain distance is proportional to the permeability of the peat. The present study showed that the $6 \mathrm{~m}$ inter-drain distance was sufficiently low to cause a fast response of the phreatic level at the centre of the drains. Soil moisture measurements suggested a dual porosity system that would allow relatively fast transfer of water through the peat. The second condition is that leakage towards the lower regional phreatic level should be limited, which requires a low permeability layer to extend below the minimum water level. This condition was not met at Zeewolde, allowing the supplied water to infiltrate in the sand layer below the peat and causing the water level to drop. In spite of this, the moisture content remained high in the peat layer at both sites, even though 2018 was an exceptionally dry year. The finegrained mineral layer capping the peat seems to have provided sufficient moisture to the crop for evaporation, while largely preventing the extraction of moisture from the peat underneath. The thin layer of sand on top of the peat layer at Zeewolde may have prevented upward flow through capillary rise, whereas drainage to the sand layer may have been minimized by the low permeability of the peat/clay layer at the base of the peat. Cracks formed in the top soil but were not deep enough to reach the peat layer. Furthermore, the farmer aims to keep cracks at minimum through surface irrigation to avoid tilt damage, in particular to onion crop.

Both the biogeochemistry and the bacterial community analyses indicated that oxygen levels in the peat remained low even in the dry summer season (sub-oxic - anoxic conditions), with very low nitrate concentrations being observed in the peat, and a decrease of sulphate concentrations observed with depth. The bacterial analysis supported the hy- drochemical observations confirming the absence of nitrification microbes and indicating that decomposition of peat in the absence of oxygen is through nitrate and sulphate reducing bacteria. The lower DNA count at depth, relative to that in the shallow sub-oxic region, suggests a decrease in the rate of peat mineralisation with depth.

Data availability. Measured groundwaterlevels are publicly accessable at http://flevoland.acaciadata.com/ (Acacia Water BV, 2017). Further data are available upon request from the authors.

Author contributions. FH and AR are responsible for the hydrological data analyses, AR is the projectleader. BLG and MW are responsible for the geochemical data analyses. MW and FH did the text writing and editing. SV performs the lab analysis of waterquality. PM performs the field measurements and installation of equipment. JV provided assistance for data analyses.

Competing interests. The authors declare that they have no conflict of interest.

Special issue statement. This article is part of the special issue "TISOLS: the Tenth International Symposium On Land Subsidence - living with subsidence". It is a result of the Tenth International Symposium on Land Subsidence, Delft, the Netherlands, 17-21 May 2021.

Acknowledgements. We are grateful to Aleida de Vos from Orvion for the contribution towards the interpretation of the microbial diversity in the soil. Stijn Groeneweg and Saline Verkerk are thanked for their assistance with analyses of water samples.

Financial support. This research has been supported by the Province of Flevoland (decision no. 1957339, file no. 1947426), LTO Noord Fondsen (project no. 16.29) and Zuiderzeeland Reigonal Water Authority (case nos. 479411 and 519214)

\section{References}

Acacia Water BV: available at: http://flevoland.acaciadata.com/, 2017.

Couwenberg, J.: Some facts on submerged drains in Dutch peat pastures, IMCG Bulletin, June/July, 9-21, 2018.

DeAngelis, K. M., Silver, W. L., Thompson, A. W., and Firestone, M. K.: Microbial communities acclimate to recurring changes in soil redox potential status, Environ. Microbiol., 12, 3137-3149, https://doi.org/10.1111/j.1462-2920.2010.02286.x, 2010.

Dong, L. F., Smith, C. J., Papaspyrou, S., Stott, A., Osborn, A. M., and Nedwell, D. B.: Changes in Benthic Denitrification, Nitrate Ammonification, and Anammox Process Rates and Nitrate and Nitrite Reductase Gene Abundances 
along an Estuarine Nutrient Gradient (the Colne Estuary, United Kingdom), Appl. Environ. Microbiol., 75, 3171-3179, https://doi.org/10.1128/AEM.02511-08, 2009.

Fokker, P. A., Gunnink, J., de Lange, G., Leeuwenburgh, O., and van der Veer, E.G.: Compaction parameter estimation using surface movement data in Southern Flevoland, Proc. IAHS, 372, 183-187, https://doi.org/10.5194/piahs-372-183-2015, 2015.

Fuerst, J. A.: Planctomycetes - New Models for Microbial Cells and Activities, chap. 1, in: Microbial Resources, From Functional Existence in Nature to Applications, edited by: Kurtböke, I., Academic Press, 1-27, 354 pp., 2017.

Leifeld, J., Müller, M., and Fuhrer, J., Peatland subsidence and carbon loss from drained temperate fens, Soil Use Manage. 27, 170 176, https://doi.org/10.1111/j.1475-2743.2011.00327.x, 2011.

Mendizabal, I.: Public supply well fields as a valuable groundwater quality monitoring network, $\mathrm{PhD}$ thesis, Vrije Universiteit, Amsterdam, 119 pp., 2011.

Preston, M. D., Smemo, K. A., McLaughlin J. W., and Basiliko, N.: Peatland Microbial Communities and Decomposition Processes in the James Bay Lowlands, Canada, Front. Microbiol., 3, 1-15, https://doi.org/10.3389/fmicb.2012.00070, 2012.
Rezanezhad, F., Price, J. S., Quinton, W. L., Lennartz, B., Milojevic, T., and van Cappellen, P.: Structure of peat soils and implications for water storage, flow and solute transport: A review update for geochemists, Chem. Geol., 429, 75-84, 2016.

Stuyfzand, P. J.: Hydrochemistry and hydrology of the coastal dune area of the Western Netherlands, PhD Thesis Vrije Universiteit, Amsterdam, 362 pp., 1993.

Tecon, R. and Or, D.: Biophysical processes supporting the diversity of microbial life in soil, FEMS Microbiol. Rev., 41, 599-23, https://doi.org/10.1093/femsre/fux039, 2017.

Velstra, J., Burger, S., van der Gaast, J., and Verbruggen, M.: Spaarwater Flevoland - Verkennen, Acacia Institute Report, 42 pp. 2015.

Vogelzang, T., Smit, B., Kuiper, P. P., and Gillet, C.: Grond in beweging; Ontwikkelingen in het grondgebruik in de provincie Flevoland in de periode tot 2025 en 2040., Wageningen Economic Research, Report 2019-00, 86 pp., 2019. 